Telegraphy. He was honoured in very numerous ways by scientific bodies in France and in other countries. In 1930 , by a special law, he was made General for life, a signal testimony to the place he had attained in the esteem of his country. Not only was he respected and admired for his ability and power, but also all who knew him loved him for his courtesy and his goodness of heart.

\section{Bequest for Bacteriology at Edinburgh}

Mrs. Cameron, widow of Lieut.-Col. Lewis Cameron, Indian Medical Service, who died at St. Helier, Jersey, in 1930, bequeathed all her estate and effects to the University of Edinburgh and directed that the fund, to be known as 'The Lewis Cameron Fund', should be utilised in establishing a yearly prize for the best paper on bacteriology or on the diagnosis of disease by students of the Uni-

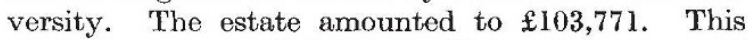
amount was regarded by the University as out of proportion to the purpose of the bequest. The University gave an undertaking to Mrs. Cameron's executors that they would make application to the Court of Session for a scheme for the regulation of the purposes affecting the estate, and on January 14 the Court approved the administration of the fund as follows: $£ 3,000$ for the establishment of two yearly 'Lewis Cameron' prizes of $£ 50$ each, one open to undergraduate students and the other to postgraduate students of the University for the best papers on subjects related to bacteriology or to the

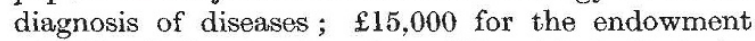
of a 'Lewis Cameron' teaching fellowship in bacterio$\operatorname{logy} ; £ 15,000$ to stabilise by endowment one of the existing lectureships in bacteriology; $£ 10,000$ to form a 'Lewis Cameron' research fund, and $£ 10,000$ for a 'Lewis Cameron' library fund to provide books relating to bacteriology and the diagnosis of disease. The remainder of the estate, about $£ 50,000$, is to be set aside as the nucleus of a building fund for providing additional accommodation and equipment in the University for teaching of the sciences bearing on the diagnosis of disease and for research in these sciences. It is hoped that allocation of this sum for buildings may enable the University to obtain assistance from other sources, and so make possible an extension of the medical buildings and of their equipment necessary to maintain the reputation of the University as a centre of medical education and research.

\section{Exhibition of Primitive and Chinese Art}

Two exhibitions of objects of art are being arranged for this year, which will be of no little scientific, as well as resthetic, interest. Of these, the first will illustrate the art of primitive peoples. This exhibition will take place in May next and will be held under the auspices of the Burlington Fine Arts Club. Although the various schools of primitive art, if that term may be used, are well, and on the whole fully, represented in the national and public collections, examples must as a rule be subordinated to the general scheme of museum arrangement, and other material distracts from their proper appreciation. If, as no doubt will be the case, representative series are shown, their close association within the compass of a single exhibition should lead, by force of comparison and contrast, to an extended perception among the general public of the variety of primitive art in ideals, technique and achievement, as well as to a clearer understanding of the part played by artistic products in relation to the life and mentality of the peoples who have produced them. On the other hand, it may be anticipated that the primitive will not be without effect on the more sophisticated culture. The influence of African art in wood and ivory carving on the development of modern schools of art in painting and sculpture early in the present century will serve as a reminder that primitive art is not without something more than antiquarian interest in the theory of æesthetic.

THe second exhibition is of an entirely different character and will be the product of international co-operation on an extended scale. The Royal Academy has arranged to hold an exhibition of Chinese art from November 1935 until March 1936. The King and Queen and the President of the Chinese Republic will be patrons, and the exhibition will be held under the auspices of the British and Chinese Governments. As it is intended that the exhibition should illustrate fully the art and culture of the Chinese from early times down to 1800, a unique opportunity will be afforded for placing China in something like true perspective in the history of world civilisation. The art of China, as is well known, played no inconsiderable part in the development of the art and culture of Western Europe from the eighteenth century onward; but this was only at a late phase in a remarkably long line of development. In this exhibition the association of 'classical' with the products of early and prehistoric culture, especially in the instance of the last-named of the more recently discovered, to which additions are being made continuously, will serve as a much-needed corrective of some popular misconceptions of the standing and achievement of the Chinese as a people. It may possibly also serve the useful purpose of stimulating a more active interest in their own antiquities among the Chinese themselves. An influential organising committee has been appointed with Lord Lytton as chairman, and Mr. Laurence Binyon, Mr. R. L. Hobson, Sir Neil Malcolm, M. Paul Pelliot and Prof. Perceval Yetts among its members. This committee will co-operate with a local Chinese committee of State officials under the presidency of the Minister for Education in the selection of exhibits from China. Other exhibits will be drawn from collections in Japan, Europe and America.

\section{History of Dyestuffs in Great Britain}

Mr. C. T. J. Cronshaw, director of the Dyestuffs Section of Imperial Chemical Industries, Ltd., is this year's Jubilee Memorial lecturer for the Society of Chemical Industry, and he spoke under the title "In Quest of Colour" before a joint meeting of that society with the Institute of Chemistry in Newcastle 